\title{
Millennial Workforce: Communicating And Multitasking
}

\author{
Sherry Robinson, Penn State University/Buskerud University College, USA
}

Hans Anton Stubberud, Buskerud University College, Norway

\begin{abstract}
The habits and behaviors of the Millennials are of some concern to employers across the Western world (Alsop, Nicholson \& Miller, 2009; McGuire, By \& Hutchings, 2007; Myers \& Sadaghiani, 2010; Smola \& Sutton, 2002). This group of people born between approximately 1979 and 1994 has grown up with communication technology and has never known a time when these conveniences were not available. People of this generation are generally thought to have different styles of and expectations for communication, both of which could have an influence on teams and organization performance (Gorman, Nelson \& Glassman, 2004; Greenbaum \& Query, 1999; Howe \& Strauss, 2000; Tapscott, 1998; Zemke, Raines \& Filipczak, 2000). Organizations may find that they need to adapt their policies and procedures in order to take advantage of the special skills offered by Millennials and minimize problems within the organization (Gursoy, Maier \& Chi, 2008).
\end{abstract}

For those Millennials pursuing higher education at the university level, going to school could be considered their primary job, with paid employment on the side. How this generation behaves in classes can be an indication of how they expect to act in their careers. Just as they use computers and smartphones to access the internet and send sms text messages and email throughout the day, (even during their college classes), they also expect to stay connected during the course of their working day, including the time spent in meetings with subordinates, peers, managers and those outside the organization. Indeed, staying connected is a central part of their lives (Frand, 2000) and they expect that others, including managers, will also use these forms of communication to stay in constant contact with them (Hagner, 2001; Robinson \& Stubberud, 2012a, 2012b). Business students are among the most eager to use technology in the classroom, and assumedly, at work (Kvavik, 2011).

To gain a better understanding of the communication behaviors of the workforce that is joining the working world, this study examines the behaviors reported by both American and Norwegian university students. Comparing the responses of students in two countries allows shows which behaviors are typical in both countries. This is important not only for managers who deal with international employees, but also for those who need to know about employees in their own countries.

Keywords: Technology; Communication; Millennials; Multitasking

\section{INTRODUCTION}

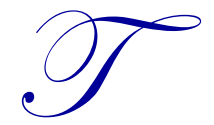

he exact year that the first Milliennials were born is a matter of some debate. While some date this generation to the late 1970s, Hershatter and Epstein (2010) match their birth to 1982 (the same year that the TCP/IP suite that gave us what we know as the internet was introduced), making them the high school graduating class of 2000. Using that specific date, this generation entered the full time workface in 2004. The habits and behaviors of the Millennials are of some concern to employers across the Western world (Alsop, Nicholson \& Miller, 2009; McGuire, By \& Hutchings, 2007; Myers \& Sadaghiani, 2010; Smola \& Sutton, 2002). Having grown up with communication technology, people of this generation are generally thought to have 
different styles of and expectations for communication, both of which could have an influence on teams and organization performance (Gorman, Nelson \& Glassman, 2004; Greenbaum \& Query, 1999; Howe \& Strauss, 2000; Tapscott, 1998; Robinson \& Stubberud, 2012b; Zemke, Raines \& Filipczak, 2000). In fact, Tapscott (2009) contends that these people are physically wired differently in that their brains have developed in different ways than those of previous generations who were not exposed to such high levels of information and communication technology. This presents both benefits and challenges for them and those with whom they interact. Support for this theory comes from neuroscience studies showing that their neural pathways have developed in such a way that they are better than previous generations at multitasking and deciphering visual stimuli, but they are less adept at communicating in face-to-face situations and interpreting non-verbal cues (Small, \& Vorgan, 2008). Another perspective is that they are able to engage in "serial focusing" (Tapscott, 2009, 97-119), which speaks to their tendencies to multitask and move quickly between subjects, or perhaps become easily distracted. Organizations may find that they need to adapt their policies and procedures in order to take advantage of the special skills offered by Millennials and minimize related problems within the organization (Gursoy, Maier \& Chi, 2008).

For those Millennials studying at the university level, pursuing higher education could be considered their primary job, while they also engage in other jobs on the side. How the students of this generation behave in their college classes and interact with instructors and other students can be an indication of how they expect to act in their careers. Just as they use computers and smartphones to access the internet and send sms text messages and email throughout the day, even during their college classes, they also expect to be able to stay connected during the course of their working day, even during meetings with subordinates, peers, managers and those outside the organization (Suchart, 2012). Staying connected almost constantly is a central part of their lives (Frand, 2000). They therefore expect that others, including managers, will also use these forms of communication to stay in constant contact with them (Hagner, 2001; Robinson \& Stubberud, 2012a, 2012b). Business students are among the most eager to use technology in the classroom, and assumedly, at work (Kvavik, 2011). A study of Millennials in the workforce in the United Kingdom found that over half of the respondents chose to respond to work email outside business hours (Jabra, 2012). Almost half of the participants reported that they use their smart phone (their own or one provided by their employer) to communicate with colleagues, supplier or customers. Multitasking was said to be a way of life for this group. Such findings have implications for how people interact with each other on the job as well as for the overall work-life balance for employees in the future.

To gain a better understanding of the communication behaviors of the workforce that is joining the working world, this study examines the behaviors reported by both American and Norwegian university students. By comparing the responses of students in two countries, it is possible to better determine which behaviors are typical in both countries and which seem to be more confined to a given culture. This is important not only for managers who deal with international employees, but also for those who need to know about employees in their own countries. The overall results show that there were, in fact, few country-based differences (between the Norwegian and American students) and few gender-based differences. However, older students (over the age of 24) were somewhat less likely than the younger students to use their phones in class or to use their laptops for activities not related to class, suggesting that the Millennial generation will be increasingly connected and engage in more and more multitasking.

The following section reviews some of the most current literature on Millennials' communication preferences and behaviors. Additional detailed results of this study are then presented, followed by discussion and conclusions.

\section{COMMUNICATION PREFERENCES}

The ways in which students communicate has obviously changed in the last few years. As technology has made it possible to stay in constant contact, people have come to expect rapid replies. Robinson (2011) has termed the rapid communication that results in a feeling of dialogue despite small time lags "k-synchronous" communication. While written communication such as that used in social networking or with mobile devices is technically asynchronous, the constant flow of replies can make it "feel" like synchronous communication. People have become used to allowing a short time for responses in such written "conversations" and can become irritated if responses are not received within a few minutes. As pointed out by Deal, Altman and Rogelberg (2010), social networking has made it easier for people anywhere in the world to engage in synchronous or asynchronous 
communication-some of which would probably be better categorized as k-synchronous communication. The MAT2R model (see Figure 1) suggests that increased use of mobile devices such as cell phones leads to increased access to electronic modes of communication (such as sms texting), which has in turn begun to alter people's perceptions of and expectations for the time it should take to receive a response to a message, such as an sms text. A response time of only a few minutes may seem like a very long time when engaging k-synchronous communication, just a few seconds can seem like a very long time when holding a conversation (dialogue).

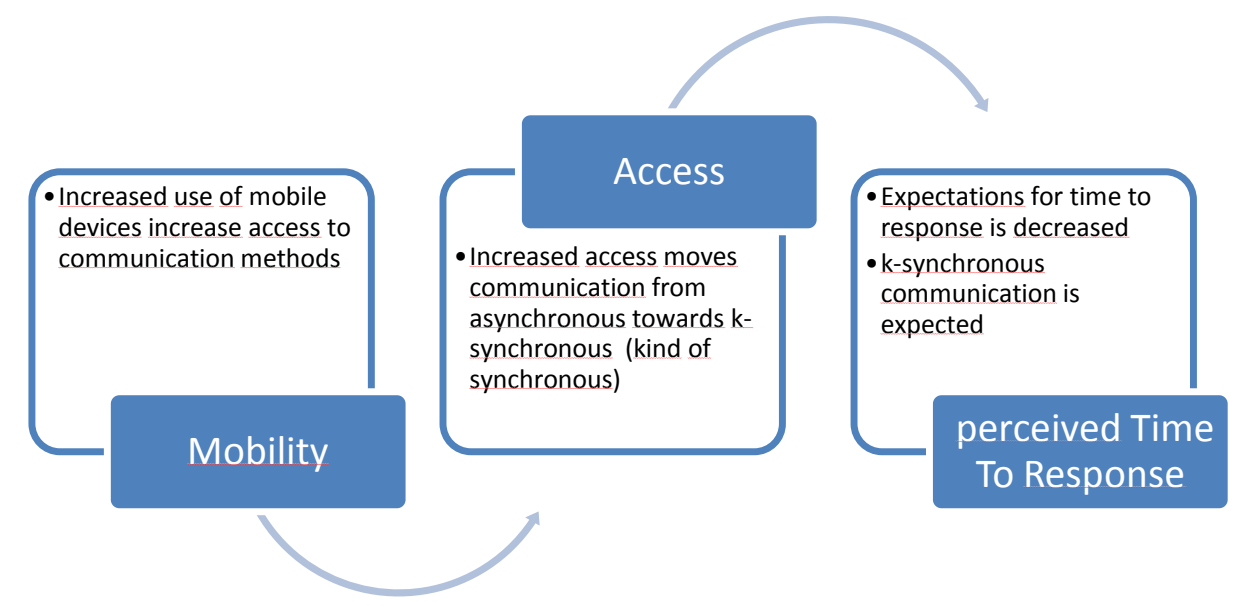

\section{Figure 1}

MAT2R Model

(reprinted with permission - source: Robinson, 2011)

A study conducted by the Pew Internet and American Life Project (Lenhart, Ling, Campbell \& Purcell, 2010) found that the mobility of cell phones, which provided greater access to communication methods, was appreciated by $92 \%$ of teens because, as one teen reported, "I can keep in touch no matter where I am" (Lenhart et al., 2010, p. 66). "No matter where I am" apparently includes "in class," as $91 \%$ of participants in a study of college students reported texting during class time (Mayk, 2011). Furthermore, approximately $10 \%$ of those students admitted to sending or receiving sms texts during exams, and 3\% confessed they had even relayed test information during the exam. The fact that sms texting is forbidden during certain times does not seem to be much of a deterrent as Lenhart (2011) found that $58 \%$ of teens in schools where phones are banned continue to send text messages during class. Students who engage in texting during exams will certainly, as employees, expect to communicate with others while also participating in work meetings.

These habits and expectations have several implications for the organization. If Millennials are more connected to each other and expect responses to messages in a shorter amount of time, the duration of a class or work meeting could seem very long. It is not a surprise that they divert their attention from the activity at hand to communicate or multitask in other ways. This tendency, along with informal communication (for example, text speak) methods may be perceived as disrespect by managers, causing problems between individuals and groups (Myers \& Sadaghiani, 2010). 
On the other hand, the expectations of those accustomed to k-synchronous communication could also benefit the organization in that Millennials expect to communicate quickly and frequently with their managers, and they are so adept at using digital media that they could easily take on the roles of lead users of communications information technology (Deloitte, 2009; Gorman et al., 2004; Gursoy et al., 2008; Hill, 2002; Marston, 2007; Martin, 2005; Pew Research Center, 2012; Robinson \& Stubberud, 2012a, 2012b; Society for Human Resource Management, 2009). They are also unconcerned about physical boundaries for communication, which could have implications for working in virtual teams across the globe (Postmes, Spears / Lea, 1998). Whether the tendency to multitask is a benefit or problem is a matter of debate (Ben-Shakhar \& Sheffer, 2001; Colom, Martinez-Molina, Shih \& Santacreu, 2010; Delbridge, 2000; Dux, Ivanoff, Asplund \& Marois, 2006; Dzubak, 2011; Grace-Martin \& Gay, 2001; Hembrooke \& Gay, 2003; Naveh-Benjamin, Craik, Perretta \& Tonev, 2000; Rubenstein, Meyer \& Evans, 2001).

\section{MULTITASKING}

There is sharp disagreement when the effectiveness of multitasking is discussed. Millennials view time as a precious resource that should be used to its fullest, leading to multitasking (Deloitte, 2009). Multitasking has been criticized for decreasing individuals' abilities to perform given tasks (Dzubak, 2011; Naveh-Benjamin et al., 2000; Rubenstein, Meyer \& Evans, 2001). Some neurscientific evidence shows that brains cannot process multiple cognitive inputs simultaneously (Dux et al., 2006). Opponents to multitasking contend that the brain can only concentrate on one activity at a time, and people who believe they are more productive when they multitask are deceiving themselves.

Other studies (Ben-Shakhar \& Sheffer, 2001; Colom et al., 2010; Delbridge, 2000) have found that some people are better at multitasking than others, and practice can improve one's ability to multitask in an effective manner. Studies involving students in classrooms (Grace-Martin \& Gay, 2001; Hembrooke \& Gay, 2003) have found that those who repeatedly looked at material unrelated to class for only a short period did better on performance tests than those who used the internet more, even when the sites they accessed were related to the lecture. This suggests that "memory decrement in multitasking situations is the results of the proportion of time drawn off task" (Hembrooke \& Gay, 2003, p. 59). Hembrooke and Gay (p. 59) concluded that "if one is adroit at staccato-like browsing, processing multiples inputs simultaneously" may not be as big a problem in mental processing as sustained internet browsing. In a similar vein, Hayles (in Glenn, 2010) contends that the "hyper attention" created by today's multimedia-rich environment is not necessarily inferior to what is normally thought of as attention. Therefore, the challenge to instructors and managers is to combine hyper attention with deep attention.

Many Millennials have become so accustomed to high levels of activity and engagement that they feel bored if they do not feel a great deal of involvement in the activity or discussion at hand. Multitasking during school hours seems to be encouraged by in-class technology access and use and can be encouraged by shots of dopamine that are received in response to stimulation (Richtel, 2010). Ferenstein (2009) labels multitasking as an essential $21^{\text {st }}$ century skill and encourages students to develop their abilities. However, he also states, "I can tell when a student loses focus on me, and I call them out. I want them to know there are consequences for failing to multi-task well" (2009, para. 3). While this may present a challenge for instructors, the problems for employers can be significant and influence the bottom line. Boredom is said to be a primary reason for premature turnover among Millennials in the workplace (Alsop, 2008).

Millennials want to be connected to their social networks almost constantly, even when they are in situations, where their attention is expected to be focused on something else, such as the course material being presented in a classroom lecture. Given the significance of this matter to organizations that are or will soon be employing people of this generation, it is important to examine how students communicate now. To gain a better understanding of student preferences and behaviors, this study shed light on the communications-related activities university students engage in while in class. The following section describes the methodology and results of this study involving university students from both the United States and Norway. 


\section{METHODOLOGY AND RESULTS}

To gain a better understanding of the ways Millennials use communication technology in class (and can be expected to use technology in the workplace) students in a basic management course at a Norwegian and an American college were asked to report on the activities they engage in during class. A total of 119 students participated, of which 56 were in the Norwegian class and 63 were in the American class. The majority (91 students) were of traditional college age (18 to 23 years old). In addition to one person who did not report his or her gender, there were 54 men and 64 women. Chi-square analyses were performed on each set of data, but the chi-square statistics and probabilities are reported only for those in which there was a statistically significant difference at less than the $\mathrm{p}<.05$ level.

As shown in Table 1, almost 97\% of students in the American school and all of the students in Norway brought their cell phones to class. This is consistent with the 95\% reported in Mayk's (2011) study. Approximately two-thirds of the participants in this study used their phones to receive (and presumably read) sms text messages during class. Nearly as many also reported sending messages during class. This was a fairly low proportion in compared to the $91 \%$ of Mayk's respondents who reporting texting during class time. About $10 \%$ admitted they received calls during class, while about 5\% used their phones to make calls during class. It is possible that students viewed breaks during long classes as part of the class, and made/received calls during these breaks, given that talking on the phone would be a behavior that is more difficult to conceal during a class compared to relatively silent texting. However, given that Lenhart (2011) found that $25 \%$ of teens have made or received calls during class time, students talking on the phone in class is a real possibility. Informal observations of those already employed in organizations suggest that taking calls (or at least leaving meetings in order to take calls) is a fairly common behavior. The results of the chi-square analysis showed no statistically significant differences between the participants in each country and suggest that the level of connectedness exhibited by Millennials is not restricted to people in the United States.

Table 1

Phone Use By School

\begin{tabular}{ccc} 
& Phone Use By School \\
\hline & Norway & USA \\
Use cell phone in class & $100 \%$ & $96.8 \%$ \\
Make call & 5.4 & 4.8 \\
Receive call & 8.9 & 11.1 \\
Send sms text & 58.9 & 60.3 \\
Receive/read sms text & 66.1 & 65.1 \\
\hline
\end{tabular}

As shown in Table 2, an examination of the behaviors regarding laptop use during class showed significant differences between the students, with the students at the Norwegian school being consistently more likely to engage in each activity except doing homework for another class and using chat (via internet). Over $62 \%$ of students at the Norwegian school brought their laptops to class. The most popular uses were taking notes, using interest for class and getting email. It should be noted that wi-fi was not available in most of the American classrooms, but there was internet access in the Norwegian classrooms. Therefore, a separate analysis was conducted among those students who brought laptops to class (35 in the Norwegian class and 8 in the American class). Among those who brought their laptops to class, there were no statistically significant differences between students at the two schools. The students at the American school who brought their laptops to class used them most for accessing the internet for class, taking notes, doing homework for class and getting email. At both schools, on-task behaviors such as taking notes and using the internet for class were some of the most popular uses of laptops, but communicating via email was almost as popular, echoing the use of cell phones in class. In this way, multitasking is made possible by internet access. These results also suggest that if students have access to the internet, they are much more likely to use it-and being in class does not stop them from using the internet for other activities. The availability of internet access also appears to encourage students to bring their laptops to class. Once they have their laptops with them, they use them for class-related activities in addition to accessing the internet for related and unrelated uses. Therefore, internet access in the classroom would appear to be a double-edged sword that simultaneously provides both benefits and challenges. 
Table 2

Laptop Use By School

\begin{tabular}{lccrc}
\hline & Norway & USA & chi-sq & p< \\
Bring laptop to class & 62.5 & 12.7 & 31.863 & .000 \\
In class use laptop for & & & & \\
Send email & 25.0 & 6.3 & 8.033 & .005 \\
Get email & 41.1 & 7.9 & 18.090 & .000 \\
Use internet for class & 46.4 & 11.1 & 18.452 & .000 \\
Use internet for another class & 19.6 & 3.2 & 8.263 & .004 \\
Take notes & 53.6 & 9.5 & 27.261 & .000 \\
Do homework for class & 26.8 & 7.9 & 7.533 & .006 \\
Homework for another class & 7.1 & 3.2 & & \\
Chat & 8.9 & 3.2 & &
\end{tabular}

Of those who bring laptops to class

Use laptop to send email

Get email

$37.1 \quad 50.0$

Use internet for another class $\quad 25.7 \quad 25.0$

Take notes $\quad 80.0 \quad 75.0$

Do homework for class $\quad 37.1 \quad 62.5$

Homework for another class $\quad 5.7 \quad 25.0$

$\begin{array}{lrr}\text { Chat } & 14.3 & 25.0\end{array}$

Table 3 presents the data by age group. Although there was a statistically significant difference between the percentage of older and younger students who brought their cell phones to class, with younger students being more likely to bring their phones to class, this difference was rather small, as over $92 \%$ of the older students also brought their phones. Statistically significant differences were not found in the comparison of specific behaviors related to cell phone use. None of the older participants admitted to make a call during class, but approximately $10 \%$ said they received calls, which was a proportion similar to the younger students. Around $44 \%$ the older students and $64 \%$ of the younger students sent sms text messages, and these proportions increased to $52 \%$ of older students and $69 \%$ of younger students when it came to receiving text messages during class. These results suggest that phone use during classes or meetings will increase, rather than decrease, over time, given that younger people have adopted these habits. These results will not come as a surprise to instructors who have observed students checking messages or texting while holding their phones under their desks.

Table 3

Phone Use By Age Group

\begin{tabular}{ccccc}
\hline & Age 18-23 & $\mathbf{2 4}$ and over & chi & p< \\
Use cell phone in class & $100 \%$ & $92.6 \%$ & 6.857 & .009 \\
Make call & 5.5 & 0 & & \\
Receive call & 9.9 & 10.7 & \\
Send sms text & 63.7 & 44.4 & \\
Receive/read sms text & 69.2 & 51.9 & & \\
\hline
\end{tabular}

Among those who brought their laptops to class (31 out of 91 younger students and 12 of 28 older students), younger students were more than twice as likely to get email (71.0\% compared to $33.3 \%)$ and to access the internet for class purposes (83.9\% vs. 41.7\%), as shown in Table 4. Given that the students in this study were in the same basic course (the differences cannot be attributed to the subject material), these differences indicate that younger students may be relying more on the internet for information, as well as for communication. The older students were most likely to take notes $(83.3 \%)$, and that was also the most popular activity among younger students (77.4\%). Although the proportions were not different at a statistically significant level, $48 \%$ of younger students reported doing homework for class compared to $25 \%$ of older students. Only younger students (13\%) admitted doing homework for another class. These results suggest that the younger students especially engage in multitasking, including working on class and non-class related activities. Such multitasking can therefore be expected to increase in the coming years. 
Table 4

Laptop Use by Age Group

\begin{tabular}{lcccc}
\hline Of those who bring laptops to class & Age 18-23 & $\mathbf{2 4}$ and over & chi & p< \\
Send email & 48.4 & 16.7 & & \\
Get email & 71.0 & 33.3 & 5.126 & .024 \\
Use internet for class & 83.9 & 41.7 & 7.659 & .006 \\
Use internet for another class & 29.0 & 16.7 & & \\
Take notes & 77.4 & 83.3 & \\
Do homework for class & 48.4 & 25.0 & \\
Homework for another class & 12.9 & 0 & \\
Chat & 19.4 & 8.3 & \\
\hline
\end{tabular}

The data were also analyzed by gender, as shown in Table 5. Although there was a statistically significant difference between men and women who get calls, the percentage was rather small (7.4\% of men compared to $10.9 \%$ of women). Again, sending and receiving sms text messages was popular with approximately two-thirds of the students.

Table 5

Phone Use by Gender

\begin{tabular}{|c|c|c|c|c|}
\hline & Men & Women & chi-sq & $\mathbf{p}<$ \\
\hline Use cell phone in class & $100 \%$ & 96.9 & & \\
\hline -make call & 3.7 & 4.7 & & \\
\hline -get call & 7.4 & 10.9 & 9.395 & .009 \\
\hline -send sms & 55.6 & 62.5 & & \\
\hline -get sms & 64.8 & 65.6 & & \\
\hline
\end{tabular}

As shown in Table 6, men who brought their laptops to class (18 out of 54 men) were more likely to use their laptops to do homework for another class (27.8\% vs. 4.2\%) than were the women who brought their laptops to class (24 out of 64 women), suggesting men may be more likely to multitask in this way. Taking notes and using the internet for class were the most popular uses, with over three-quarters of the students engaging in these activities. However, sending and receiving emails and using the internet for another class were also activities reported by a considerable proportion of students, again indicating multitasking and keeping in touch via electronic means.

Table 6

Laptop Use by Gender

\begin{tabular}{lllll}
\hline Of those who bring laptops to class & Men & Women & chi-sq & p< \\
Send email & 44.4 & 37.5 & & \\
Get email & 55.6 & 70.8 & \\
Use internet for class & 83.3 & 75.0 & \\
Use internet for another class & 25.0 & 38.9 & \\
Take notes & 83.3 & 87.5 & & \\
Do homework for class & 61.1 & 37.5 & & \\
Homework for another class & 27.8 & 4.2 & 6.125 & .015 \\
Chat & 16.7 & 16.7 & & \\
\hline
\end{tabular}

Overall, the results show that students, especially those who have access to the internet in the classroom, are using their laptops and the internet for class. They take notes, do homework and look at class-related internet sites. But they also use the internet for other projects and to send and receive email during class. Multitasking, whether it is related to social communication or school work, is clearly a prevalent practice. These results are consistent with the conclusions drawn by Hembrooke and Gay (2003), who encouraged students to bring their laptops to class and use them as a supplement to the class activities. Students did indeed use the internet to explore lecture topics in greater detail during the lectures, but they also communicated via email and chat and browsed the internet for content unrelated to the class. 


\section{DISCUSSION AND CONCLUSION}

The results of this study suggest that the use of technology for communication even during class is likely to increase rather than decrease, and it can be expected that these students will treat work meetings in the same way. Only a few statistically significant differences were found between younger and older students, but in every case, the younger students were more likely to use technology and communicate while in class. One alternative for handling this situation is to ban technology for personal communications, while another is to ignore it. We argue that a third alternative, embracing technology and using it as a class/work tool to help engage students (and eventually workers), is a more practical and proactive approach to this problem and can help turn a negative situation into a positive one.

To provide a "backchannel" for student communication during class, Purdue University has developed a "Hotseat" application that combines various social media such as Facebook, Twitter and sms texting (Dybwad, 2009). Students can post messages during class and read others' comments. It is reported that students are interacting more in the class and asking more relevant questions. Workplace wikis would provide a similar outlet as well as a depository for information that could be important to other workers.

Millennials' use of technology in the college classroom must provide both pedagogical and course-specific dividends so that students can use technology as a learning tool. Likewise, managers of Millennials will need to be aware of their habits and expectations to increase productivity as well as worker satisfaction. Organizations can also take advantage of the habits Millennials have developed in terms of communication and connectedness (Gursoy, Maier \& Chi, 2008). For example, employees of this generation are likely to be very adept at working with social media to communicate with both those in and outside of the organization. In the future, Millennials will become a major segment of the workforce, bringing their habits and expectations with them. By working with this group rather than insisting that they conform to the methods of the past, organizations may gain a competitive advantage in terms of human resources.

\section{AUTHOR INFORMATION}

Sherry Robinson conducts research on entrepreneurship, the use of mobile devices, and learning games at The Pennsylvania State University, USA, and Buskerud University College, Norway. E-mail: Skr12@psu.edu (Corresponding author)

Hans Anton Stubberud conducts research on entrepreneurship, the use of mobile devices, and learning games at The Pennsylvania State University, USA, and Buskerud University College, Norway. E-mail: Hansanton.stubberud@hibu.no

\section{REFERENCES}

1. Alsop, R., P Hicholson, \& J. Miller. (2009). Gen Y in the workforce commentary. Harvard Business Review, 87(2), 43-49.

2. Ben-Shakhar, G. \& L. Sheffer. (2001). The relationship between the ability to divide attention and standard measure of general cognitive abilities. Intelligence, 29 293-306.

3. Colom, R., A. Martinez-Molina, P.C. Shih, P.C. \& J. Santacreu. (2010). Intelligence, working memory, and multitasking performance. Intelligence, 38, 543-551.

4. Corbeil, J. R. \& M. E. Valdes-Corbeil. (2007). Are you ready for mobile learning? EDUCASE Quarterly,30(2). Retrieved 25 October, 2011, from http://www.educause.edu/EDUCAUSE+Quarterly/EQVolume302007/EDUCAUSEQuarterlyMagazineVol $\underline{\mathrm{um} / 157459}$

5. Deal, J. J., D. G. Altman, \& S. G. Rogelberg. (2010). Millennials at work: what we know and what we need to do (if anything). Journal of Business Psychology, 25, 191-199.

6. Delbridge, K.A. (2000). Individual Differences in Multi-Tasking Ability: Exploring A Nomological Network. Unpublished Doctoral Dissertation, University of Michigan, East Lansing.

7. Deloitte. (2009). State of the media democracy survey ( $3^{\text {rd }}$ ed.). Retrieved 1 July, 2010, from http://www.deloitte.com/us/realitycheck 
8. Dux, P. E., J. Ivanoff, C. L. Asplund, \& R. Marcois. (2006). Isolation of a centra bottleneck of information processing with time-resolved fMRI. Neuron, 52, 1109-1120.

9. Dybwad, B. (2009). Purdue University Adds Twitter and Facebook to Class Participation. Retrieved 24 October, 2011, from http://mashable.com/2009/11/03/hotseat/

10. Dzubak, C. M. (2011). Multitasking: The good, the bad, and the unknown. Retrieved 22 November, 2011, from http://www.myatp.org/Synergy_1/Syn_6.pdf

11. Ferenstein, G. (2009). Why I Let My Students Use Facebook During Class. Retrieved 24 October, 2011, from http://www.fastcompany.com/blog/gregory-ferenstein/fastminds/why-i-let-my-students-use-facebookduring-class

12. Frand, J. (2000). The Information-age mindset. EDUCAUSE Review, September/October. Retrieved February 24, 2011 from http://www.educause.edu/apps/er/erm00/articles005/erm0051.pdf

13. Glenn, D. (2010). Divided Attention. Retrieved 22 November, 2011, from http://chronicle.com/article/Scholars-Turn-Their-Attention/63746/

14. Gorman, P., T. Nelson, \& A. Glassman. (2004). The Millennial generation: A strategic opportunity. Organizational Analysis, 12(3), 255-270.

15. Greenbaum, H. H. \& J. L. Query, Jr. (1999). Communication in organizational work groups: A review and analysis of natural work group studies. In L. R. Frey /Ed.), The handbook of group communication theory and research (pp. 539-564). Thousand Oaks, CA: Sage.

16. Gursoy, D., T. A. Maier, \& C. G. Chi. (2008). Generational differences: An examination of work values and generational gaps in the hospitality workforce. International Journal of Hospitality Management, 27, 458-488.

17. Hagner, P. (2001). "Interesting Practices and Best Systems in Faculty Engagement and Support," final report to the National Learning Infrastructure Initiative (January 25, 2001). Retrieved 25 October, 2011, from http://www.educause.edu/ir/library/pdf/NLI0017.pdf.

18. Hembrooke, H. \& G. Gay. (2003). The laptop and the lecture: The effects of multitasking in learning environments. Journal of Computing in Higher Education, 15(1), 46-64.

19. Hershatter, A. \& M. Epstein. (2010). Millennials and the world of work: An organization and management perspective. Journal of Business Psychology, 25, 211-223.

20. Hill, R. P. (2002). Managing across generations in the $21^{\text {st }}$ century: Important lessons from the ivory trenches. Journal of Management Inquiry, 11(1), 60-66.

21. Howe, N. \& W. Strauss. (2000). Millennials rising. New York: Vintage Books.

22. Jabra. (2012). GenM: Defining the workforce of tomorrow. Retrieved 15 June, 2012, from www.jabra.co.uk

23. Kravik, R. (2011). Convenience, communications, and Control: How Students Use Technology. Retrieved 25 October, 2011, from http://www.educause.edu/Resources/EducatingtheNetGeneration/ConvenienceCommunicationsandCo/607 $\underline{0}$

24. Lenhart, A. (2010). Facebook message - some say it's an "email killer," others disagree, Pew Internet data shows us where email stands today among youth. Retrieved February 4, 2011, from www.pewinternet.org/Commentary/2010/November/Pew-Internet-Data-Provides-Context-for-theFacebook-Messages-Announcement.aspx

25. Lenhart, A. (2011). Teens, Cell Phones and Texting. Retrieved 24 October, 2011, from http://bcsdcybercrimes.com/Documents/Teens, \%20Cell\%20Phones\%20and\%20Texting.pdf

26. Lenhart, A., R. Ling, S. Campbell \& K. Purcell. (2010). Teens and mobile phones. Washington, D.C. Pew Internet \& American Life Project.

27. Marston, C. (2007). Motivation the "What's in it for me?" workforce: Manage across the generational divide and increase profits. Hoboken: Wiley.

28. Martin, C. A. (2005). From high maintenance to high productivity: What managers need to know about Generation Y. Industrial and Commercial Training, 37, 39-44.

29. Mayk, V. (2010). Wilkes University Professors Examine Use of Text Messaging in the College Classroom. Retrieved October24, 2011, from http://www.wilkes.edu/pages/194.asp?item=61477

30. McGuire, D., R. T. By, \& K. Hutchings. (2007). Towards a model of human resource solutions for achieving intergenerational interaction in organizations. Journal of European Industrial training, 31, 592608 . 
31. Myers, K. K. \& K. Sadaghiani. (2010). Millennials in the workplace: A communication perspective on millennials' organizational relationships and performance. Journal of Business Psychology, 25, 225-238.

32. Naveh-Benjamin, M., F. I. Craik, J. G. Perretta, \& S. T. Tonev. (2000). The effects of divided attention on encoding and retrieval processes: The resiliency of retrieval processes. The Quarterly Journal of Experimental Psychology, 53A (3), 609-625.

33. Ohio State University Office of Student Life. (2010). 2010 Student Technology Survey lpsl.coe.uga.edu/Projects/AAlaptop/.../initial_student_revisedUS.pdf

34. Pew Research Center. (2012). The Millennials: Confident. Connected. Open to change. Retrieved 15 June, 2012, from http://pewresearch.org/millennials/

35. Postmes, T., R. Spears \& M. Lea. (1998). Breaching or building social boundaries? SIDE-effects of computer-mediated communication. Communication Research, 25(6), 689-715.

36. Richtel, M. (2010). Attached to technology and paying a price. The New York Times. June 6, 2010.

37. Robinson, S. (2011). MAT2R Model. Retrieved November 18, 2011 from www.personal.psu.edu/skr12

38. Robinson, S. \& Stubberud, H.A. (2012a). Student preferences for educational materials: Old meets new.

39. Academy of Educational Leadership Journal, 16(special issue), 99-110.

40. Robinson, S. \& Stubberud, H.A. (2012b). Communication Preferences Among University Students. Academy of Educational Leadership Journal, 15(3), 105-113.

41. Rubinstein., D.E. Meyer, \& J.E. Evans. (2001). Executive control of cognitive processes in task switching. Journal of Experimental Psychology: Human Perception and Performance, 27(4), 763-797.

42. Small, G. \& Vorgan, G. (2008). iBrain: Surviving the technological alternation of the modern mind. New York: Harper Collins.

43. Smola, K. W. \& C. D. Sutton. (2002). Generational differences: Revisiting generational work values for the new millennium. Journal of Organizational Behavior, 23 363-382.

44. Society for Human Resource Management. (2009). The multigenerational workforce: Opportunity for competitive success. Retrieved 30 May, 2012, from http://www.shrm.org/Research/articles/Articles/Documents/09-0027_RQ_March_2009_FINAL_noad.pdf

45. Suchart, W. (2012). Social media privacy and your Millennial workforce. Retrieved 1 June, 2012, from http://itknowledgeexchange.techtarget.com/cio/social-media-privacy-and-your-millennial-workforce

46. Student Voices Forum. (2009). Retrieved February 24, 2011, from cos.edu/.../COS\%20Student\%20Voices\%20Forum\%20Presentation.ppt

47. Tapscott, D. (1998). Growing up digital: The rise of the net generation. New York: McGraw-Hill.

48. Tapscott, D. (2009). Grown up digital. New York: McGraw Hill.

49. Zemke, R., C. Raines, \& B. Filipczak. (2000). Generations at work: Managing the clash of the veterans, Boomers, Xers, and Nexters in your workplace. New York: AMACOM American Management Association. 